\title{
Salinity-induced changes in the morphology, physiology, and anatomy of seeds and seedlings of smooth narra (Pterocarpus indicus Willd. f. indicus)
}

\author{
MARJORIE M. MANIPOL ${ }^{1, \vartheta}$, CRUSTY E. TINIO ${ }^{2}$, LERMA SJ. MALDIA ${ }^{2}$, MARILYN S. COMBALICER ${ }^{2}$ \\ ${ }^{1}$ Forest Management Bureau, DENR Compound. Visayas Avenue, Diliman, Quezon City, Philippines. Tel.: +63-2-8927-4788, Fax.: +63-2-89289313, \\ remail: mmmanipol@up.edu.ph \\ ${ }^{2}$ Department of Forest Biological Sciences, College of Forestry and Natural Resources, University of the Philippines Los Baños. \\ College, Laguna 4031, Laguna, Philippines. Tel: +63-922-8140447, ${ }^{*}$ email: mscombalicer@up.edu.ph
}

Manuscript received: 11 August 2020. Revision accepted: 13 October 2020.

\begin{abstract}
Manipol MM, Tinio CE, Maldia LSJ, Combalicer MS. 2020. Salinity-induced changes in the morphology, physiology, and anatomy of seeds and seedlings of smooth narra (Pterocarpus indicus Willd. f. indicus). Biodiversitas 21: 5146-5154. Pterocarpus indicus Willd. forma indicus is a commonly planted species for reforestation in the Philippines regardless of the area's condition. Since the species could survive in areas even with harsh conditions, it was hypothesized that the species may also thrive in areas having substantial amount of salt, especially during its early growth. This study assessed the morphological, physiological, and anatomical responses of seeds and seedlings of $P$. indicus Willd. f. indicus (Fabaceae), a native species in the Philippines to varying salt (NaCl) concentrations (0-300 mM). Based on the results, P. indicus f. indicus grew significantly in terms of height, number of leaves, leaf area, root collar diameter (RCD), root nodules, and root-shoot ratio in the control and at $100 \mathrm{mM} \mathrm{NaCl}$. On the other hand, the growth of the species was suppressed at $300 \mathrm{mM} \mathrm{NaCl}$. The physiological characteristics (germination, survival, and photosynthetic rates) were also high in the control compared to the $\mathrm{NaCl}$ treatments. As for the seed anatomical characteristics, the radicle cells remained undamaged, with high cell number and longer cells in the control, but showed damaged and reduced cell number and length at $300 \mathrm{mM} \mathrm{NaCl}$. This indicates that $P$. indicus f. indicus can only tolerate moderate saline soil conditions. Hence, this result needs to be considered in reforestation efforts of the country using this species.
\end{abstract}

Keywords: Nitrogen-fixing species, photosynthetic rate, radicle, salt stress, sodium-chloride

Abbreviations: BSWM: Bureau of Soils and Water Management, CFNR: College of Forestry and Natural Resources, DFBS Department of Forest Biological Sciences, MMFR: Mount Makiling Forest Reserve, $\mathrm{P}_{\mathrm{N}}$ : net photosynthesis, PAR: photosynthetic active radiation, PPFD: photosynthetic photon flux density, RCD: root collar diameter, UPLB: University of the Philippines Los Baños

\section{INTRODUCTION}

Salinity is an environmental stress that limits plant growth and productivity around the world. This problem is most prevalent in India, Pakistan, China, Syria, Iraq, Australia, and the United States (Qadir et al. 2014). Although in the Philippines saline-prone areas are small compared to other countries, there are about 600,000 ha of saline soil sites in the country (BSWM 2018) that need to be managed. Increased soil salinity induces changes in the morphology, physiology, and anatomy of the plants (Poljakoff-Mayber 1975; Huang and Redmann 1995; Vijayan et al. 2008; Rajabpoor et al. 2014; Hasanuzzaman et al. 2018). In many studies, it was reported that the high soil salinity mostly causes anatomical alterations such as reduction in aerenchyma (Naidoo and Mundree 1993), cortex thickness (Dolatabadian et al. 2011), xylem thickness, diameter of the vessels, stomatal index (Akcin et al. 2017), and stomatal density (Jafri and Ahmad 1995). Salinity also causes significant reduction in photosynthetic pigments, some mineral contents, and the level of total carbohydrates (Dawood et al. 2014). Plant roots treated with $\mathrm{NaCl}$ were observed shorter and had less secondary roots (Cachorro et al. 1995). In contrast, a significant increase in pith diameter of the stem (Akcin et al. 2017), upper and lower epidermis of leaf, palisade and spongy mesophyll (Boughalleb et al. 2009; Jafri and Ahmad 1995), stomatal size (Jafri and Ahmad 1995), and root-shoot ratio (Acosta-Motos et al. 2015) was observed with increased salinity levels. Other biochemical changes occurred in saltstressed plants such as an increase in osmoprotectants and activities of antioxidant enzymes (Dawood et al. 2014). This information needs to be considered in selecting salttolerant species necessary for sustainable plant productivity (Fall et al. 2016).

Pterocarpus indicus Willd. f. indicus (Smooth Narra) is a native species in the Philippines belonging to the family Fabaceae. It grows up to $35 \mathrm{~m}$ height in primary and secondary forests at low and medium altitudes. It usually blooms annually from early March to late September, but most young fruits develop from April to June and mature ones from July to the following year. It has a $\mathrm{C}_{3}$ photosynthetic pathway, which is common to most trees (Kozlowski and Pallardy 1997). This species is recognized for its hardiness, rapid growth, and a promising species for reforestation due to its nitrogen-fixing ability (Thomson 2006). It is one of the recommended species for the National Greening Program (Executive Order No. 26) of 
the Philippines which encourages the use of native or indigenous species. However, the success of any planting activity depends on how plants respond to the given site conditions. But there is still a lack of such information available. Few studies have been conducted to determine the effects of environmental factors on $P$. indicus seedlings. These include the studies of Baek and Woo (2010) on the effect of different air pollutant levels to the physiological and biochemical of $P$. indicus, Baek et al. (2018) on the effect of elevated ozone under well-watered and drought conditions, and Lok and Dell (2015) on the effect of phosphorus deficiency on the growth of $P$. indicus seedlings. Other related studies on $P$. indicus seedlings include the nursery seedling grading by Gazal et al. (2004), storage of seeds by Krishnapillay et al. (1994), and seedling growth technique for Pterocarpus spp. by $\mathrm{Xu}$ et al. (2004).

Several studies have also shown the effect of salinity such as in the study of Caesalpinia crista where seed germination and seedling growth were retarded (Patel et al. 2011), in the study of Trifolium repens where $\mathrm{Mg}$ in tissue was reduced (Cekstere et al. 2015), and in the study of Fabaceae species in Thailand where a slow rate of germination was observed as salinity levels increased $(\mathrm{Ku}-$ Or et al. 2020). However, no study has yet been conducted to determine the effect of salinity on the seeds and seedlings of $P$. indicus. Little is known about the mechanisms enabling trees to cope with high salinity for extended periods. Hence, in this study, we examined the effects of different salinity levels on the morphological, physiological, and anatomical structures of $P$. indicus $\mathrm{f}$. indicus.

\section{MATERIALS AND METHODS}

Two pot experiments were established to determine the effects of varying salinity levels on the morpho-physiology and anatomy of the seeds and seedlings of $P$. indicus $\mathrm{f}$. indicus. The seeds were used to determine the germination rate and to characterize the anatomy, while the seedlings were used to evaluate the percentage survival, morphological parameters, and photosynthetic rate.

\section{Study area and pod collection}

The experiment was conducted from August 2016 up to March 2017 in the nursery and Microtechnology Laboratory of the DFBS, CFNR, UPLB, Laguna, Philippines. The pods were collected from one of the identified candidate mother trees of $P$. indicus $\mathrm{f}$. indicus (Smooth Narra) tagged in MMFR (elevation: $121 \mathrm{~m}$ a.s.1.; $14^{\circ} 9^{\prime} 18.5^{\prime \prime} \mathrm{N}$ and $121^{\circ} 14^{\prime} 7.8^{\prime \prime} \mathrm{E}$ ). The tagged mother tree generally blooms annually and consistently provides a large number of pods. The collected pods contain three or more seeds. The pods were air-dried for two weeks prior to seed extraction. The extracted seeds were then subjected to the floatation test method to select viable seeds (Dayan and Reaviles 1995).

\section{Experimental design and set-up}

The experiment was performed using a simple complete randomized design with four treatments, including the control, having three replicates of 50 seeds, and 50 seedlings per replicate. There were 150 seeds and 150 seedlings per treatment, and a total of 600 seeds and seedlings. Garden soil was used as the potting environment for the seeds. The seedlings used were grown from seeds of different selected mother Smooth Narra trees in MMFR. We used only healthy and of uniform size six-month-old seedlings of $P$. indicus $\mathrm{f}$. indicus without any deformations such as leaf defoliation and leaf rolling.

This study used four treatments, including the control (distilled water) and three different salt concentration levels $(100,200$, and $300 \mathrm{mM})$. In previous studies on the effects of salinity on plant growth, minimal levels of salt concentration (i.e., $25 \mathrm{mM}, 50 \mathrm{mM}, 75 \mathrm{mM}, 90 \mathrm{mM}$ ) did not yield a significant effect on the morphology as well as physiological functions (Glenn et al. 1999). Thus, in this study, the concentration levels were elevated from $100 \mathrm{mM}$ in order to observe potential considerable changes. The salt solutions were prepared by dissolving $58.4 \mathrm{~g}, 116.9 \mathrm{~g}$, and $175.3 \mathrm{~g}$ of sodium chloride $(\mathrm{NaCl})$ in $1 \mathrm{~L}$ of water to make the 100,200 , and $300 \mathrm{mM} \mathrm{NaCl}$ solution, respectively. Seeds were soaked for 24 hours in each salt concentration and were germinated and examined for the anatomical changes $(n=60)$. The seedlings were watered $(125 \mathrm{~mL})$ twice a week at 08:00 a.m. for about two months. Observations were done every two weeks to assess seedling survival.

\section{Morphological characteristics}

The number of leaves, leaf area, height (stem length), number of root nodules, root collar diameter, and rootshoot ratio were measured in the laboratory. The number of leaves and number of root nodules was counted, while the height and RCD were measured using a ruler $(\mathrm{cm})$ and digital vernier caliper ( $\mathrm{mm})$, respectively.

To determine the root-shoot weight ratio (Rogers et. 2019), oven-dry method was used by separating the root and the shoot of the seedlings. The leaf area was determined by the grid method (Dey et al. 2019) using a graphing paper (for tracing the leaves). In the seed experiment, shape, color, and size were also observed in the laboratory. The formulae used to compute for rootshoot ratio and leaf area are as follows:

$$
\text { Root }- \text { Shoot Ratio }=\frac{\text { Dry wt. of roots }}{\text { Dry wt. of stem }}
$$

Leaf Area $\left(\mathrm{cm}^{2}\right)=$ Area of 1 grid $\mathrm{x}$ Total number of grids

\section{Physiological characteristics}

For the survival percentage (Mishra et al. 2015) of seedlings, the following formula was used:

$$
\text { Survival percentage }=\frac{\text { Number of Seedlings Alive }}{\text { Number } \text { of Seedlings Used }} \times 100
$$


To determine the photosynthetic rates of the plants subjected to salt stress, the uptake of $\mathrm{CO}_{2}$, production of $\mathrm{O}_{2}$, production of carbohydrates, and increase in dry mass of the seedlings were measured using the Portable Photosynthesis System (LI-COR) 6400 (Li-Cor Inc., NE, USA). Firstly, the LI-COR was stabilized at a relative humidity of $63 \%, \mathrm{CO}_{2}$ concentration of $400 \mathrm{ppm}$, and a temperature of $33.86{ }^{\circ} \mathrm{C}$. When already stabilized, the leaves were inserted in the leaf chamber. The leaves were kept intact on the seedling $(n=60)$ during the measurement. The third leaf from the shoot of the seedlings, with an approximate leaf area of $4 \mathrm{~cm}^{2}$, was used in the data collection. The observation period was from 08:00 a.m. until 04:00 p.m.

\section{Seed anatomical characteristics}

The transverse sections of the seeds $(n=60)$ were obtained following the procedures of Johansen (1940). In each treatment, the specimens were randomly selected and cut into small pieces by $3 \mathrm{~mm}$ without damaging the radicle part. These were fixed in 1:1 ratio of FAA solution (Formalin: Acetic acid: Alcohol) for $2 \mathrm{~h}$. Then, these samples were dehydrated in ethanol series for seven days. After dehydration, the samples were embedded into melted paraffin wax. The samples embedded in the wax were sectioned into thin slices of 10-15 $\mu \mathrm{m}$ using the microtome blade. The sections were stained with Safranin and Fast Green Dye solution. After staining, the specimens were coated with Entelan solution and then air-dried.

For the microscopic examination of the seeds, a compound microscope (Olympus CX 21) was used at the FBS Laboratory of CFNR-UPLB. The magnification used for photomicrographs were $100 \mathrm{x}$ and $400 \mathrm{x}$. Identification of the structures of the radicle tissue was observed, while the number of cells and cell sizes were counted and measured, respectively. A total of 5 seeds per replicate (3 replicates) under various treatments (4 treatments) were used to characterize the anatomy. Haupt (1953), Fahn (1967), Bell (2008), and Shipunov (2020) were followed to describe the anatomy of the plant.

\section{Statistical analysis}

The one-way analysis of variance (ANOVA) and Duncan's multiple range test (DMRT) was used to test the significance of the mean differences of $P$. indicus $\mathrm{f}$. indicus in terms of height, number of leaves, leaf area, RCD, number of root nodules, root-shoot ratio, seed germination rate, and survival rate of the seedlings. All analyses were performed in R Studio version 4.0 (R Studio Team 2015).

\section{RESULTS AND DISCUSSION}

\section{Morphological and physiological characteristics}

The effects of varying salt concentrations on different morphological parameters of $P$. indicus $\mathrm{f}$. indicus seedlings are presented in Table 1. In general, the six morphological parameters, except the leaf area, decreased significantly $(P$ $<0.05)$ as the salt concentration increased. The leaf area $\left(\mathrm{cm}^{2}\right)$ showed no significant difference across the varying salt concentration.

\section{Physiological characteristics}

The effects of varying salinity of the physiological characteristics of $P$. indicus $\mathrm{f}$. indicus seedlings are presented in Figures 1 and 2. It can be readily gleaned in these figures that seed germination, seedling survival, and photosynthetic rates progressively decrease with increasing salinity levels.

\section{Seed germination and seedling survival}

Both the mean seed germination and seedling survival percentages of the three salt concentrations were significantly different from the control and generally with each other (Figure 1.A and 1.B).

\section{Photosynthetic rate}

The photosynthetic rates of seedlings measured in all the treatments are shown in Figure 2. Increasing photosynthetic rates with PAR increased was observed in the control and also a less deep increase was observed under $100 \mathrm{mM}$ and $200 \mathrm{mM}$ treatments. There were significantly similar photosynthetic rates among the three varying salt concentrations and these were significantly lower than the control $(P<0.0123)$.

Table 1. Effect of three $\mathrm{NaCl}$ concentrations on the morphology of $P$. indicus f. indicus seedlings. Standard errors are in parentheses

\begin{tabular}{ccccccc}
\hline $\begin{array}{c}\text { NaCl } \\
(\mathbf{m M})\end{array}$ & $\begin{array}{c}\text { Seedling height } \\
(\mathbf{c m})\end{array}$ & Leaf number & Leaf area $\left(\mathbf{c m}^{2}\right)$ & $\begin{array}{c}\text { Root collar } \\
\text { diameter }(\mathbf{m m})\end{array}$ & $\begin{array}{c}\text { Root nodules } \\
\text { Root-Shoot } \\
\text { ratio }\end{array}$ \\
\hline 0 & $13.26(0.10)^{\mathrm{a}}$ & $7.55(0.16)^{\mathrm{a}}$ & $2.62(0.29)^{\mathrm{a}}$ & $1.69(0.06)^{\mathrm{a}}$ & $22.67(1.76)^{\mathrm{a}}$ & $0.55(0.03)^{\mathrm{a}}$ \\
100 & $12.90(0.02)^{\mathrm{b}}$ & $5.77(0.39)^{\mathrm{b}}$ & $2.52(0.22)^{\mathrm{a}}$ & $1.60(0.02)^{\mathrm{ab}}$ & $17.33(4.33)^{\mathrm{ab}}$ & $0.51(0.00)^{\mathrm{a}}$ \\
200 & $12.75(0.05)^{\mathrm{bc}}$ & $3.29(0.67)^{\mathrm{c}}$ & $2.46(0.17)^{\mathrm{a}}$ & $1.61(0.05)^{\mathrm{ab}}$ & $9.33(2.60)^{\mathrm{bc}}$ & $0.48(0.02)^{\mathrm{ab}}$ \\
300 & $12.63(0.02)^{\mathrm{c}}$ & $1.50(0.27)^{\mathrm{d}}$ & $2.25(0.30)^{\mathrm{a}}$ & $0.88(0.45)^{\mathrm{b}}$ & $2.67(1.45)^{\mathrm{c}}$ & $0.39(0.05)^{\mathrm{b}}$ \\
\hline
\end{tabular}

Note: Different superscripted letters within a column indicate statistically significant differences among the treatments according to Duncan Multiple Range Test (DMRT) $(P<0.05)$ 
(A)

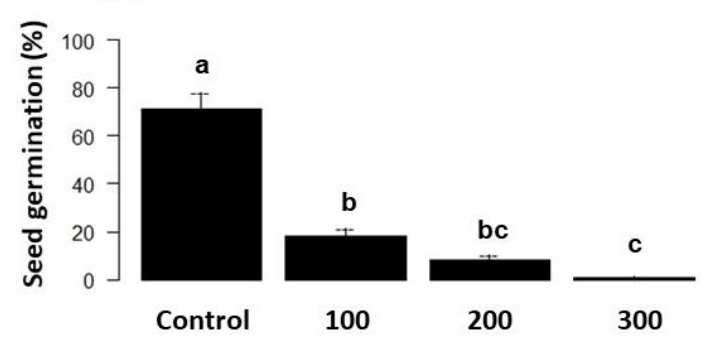

(B)

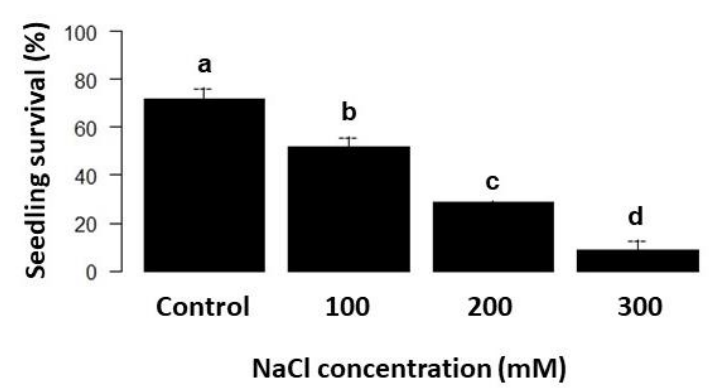

Figure 1. Effect of the varying $\mathrm{NaCl}$ concentrations on the (A) seed germination (in \%) and (B) seedling survival (in \%) of Pterocarpus indicus f. indicus. Different letters indicate statistically significant differences among the treatments according to DMRT $(\mathrm{P}<0.05)$

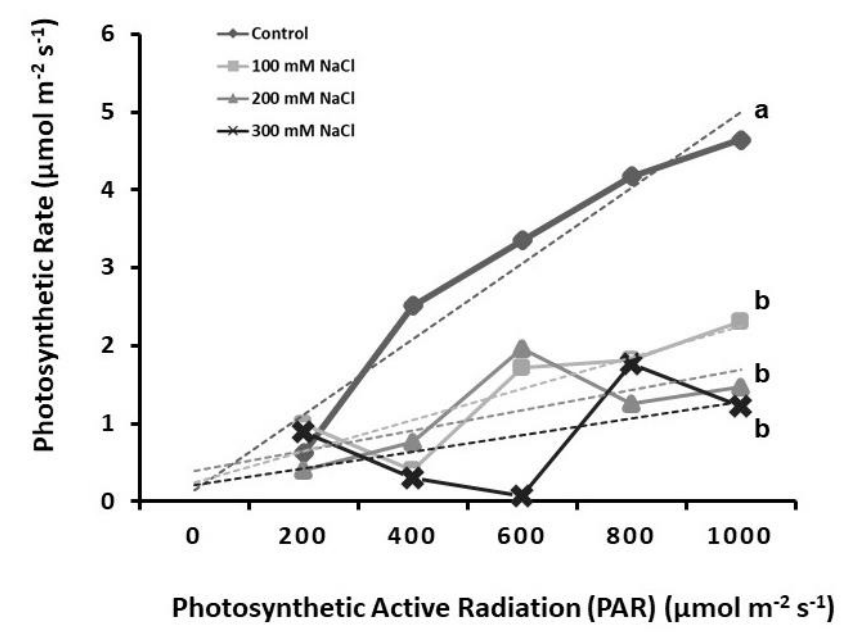

Figure 2. Mean photosynthetic rates of Pterocarpus indicus $\mathrm{f}$. indicus in all the $\mathrm{NaCl}$ concentrations. Significantly different $(P<$ 0.05 ) treatment results bear different letters

\section{Seed anatomical characteristics}

The Smooth Narra seeds are flattened, bean-shaped with a size of 6-8 $\mathrm{mm}$ long and with a leathery, brittle seed coat. The transverse sections of the seed specifically the radicle is shown in Figure 3. The seed radicle was examined because it is where the primary root occurs. The images shown were viewed under 100x. The figure shows that as $\mathrm{NaCl}$ increases the cell structure differs from that of the control. In Figure 3.A (control), the structure of the radicle had no abnormalities. There was no evidences that the cells are damaged. In Figure 3.B (100 mM), the radicle (left) exhibited partly ruined cells and appeared to have tiny black spots in the radicle tissue (right). On the other hand, in Figure 3.C (200 mM) the radicle tissue showed more spatially distributed damaged cells (left), and similar to Figure 3.B, black spots could be observed inside the cells. In Figure 3.D (300 mM), more damaged cells were observed compared to the other treatments applied. Both Figure 3.C and 3.D showed damage cells of the radicle tissue.

The images on the right panel of Figure 3 showed the representative images of the radicles of the control and at those of the varying $\mathrm{NaCl}$ treatments at the higher magnification. Cells were counted from a sample within a box of $1 \mathrm{~cm}^{2}$ in the middle of the radicle to eliminate variation. In the control, the number of cells per box ranges from 50 to 100 cells; 30 to 50 in $100 \mathrm{mM}$; and, at most 30 cells in $200 \mathrm{mM}$ and $300 \mathrm{mM}$. This clearly showed that the number of cells decreased as the $\mathrm{NaCl}$ concentration increased. In the $200 \mathrm{mM}$ and $300 \mathrm{mM} \mathrm{NaCl}$, the cells were no longer intact compared to the control and $100 \mathrm{mM}$ $\mathrm{NaCl}$. The cell sizes were also measured and compared $(n=60)$. In control, the length of the cell varies from 1 to 4 $\mu \mathrm{m}$; in $100 \mathrm{mM}$ the lengths are less than 1 to $3 \mu \mathrm{m}$, and in $200 \mathrm{mM}$ and $300 \mathrm{mM}$ the lengths are less than 1 to $2 \mu \mathrm{m}$ each.

\section{Discussion}

This study showed that $P$. indicus f. indicus generally affected both morphologically and physiologically during the early stage of its growth (Table 1). The decrease in the height of seedlings with increasing $\mathrm{NaCl}$ concentrations in this study is similar to the results of other salinity-related studies. For instance, there was a significant reduction in height increment of Pteroceltis tatarinowii with increasing $\mathrm{NaCl}$ concentration 50 days after treatment (Fang et al. 2006). Also, at $150 \mathrm{mM} \mathrm{NaCl}$ the growth of Phaseolus coccineus and $P$. vulgaris were reduced by $40 \%$ (Hassan et al. 2016). In contrast, there are species that can tolerate high saline conditions such as mangroves species. For example, Avicennia officinalis' growth was attributed to the increase in $\mathrm{NaCl}$ concentration up to $128 \mathrm{mM}$ (Saravanavel et al. 2012). For salt-tolerant species like Atriplex portulacoides, a range from $200 \mathrm{mM}$ to $700 \mathrm{mM} \mathrm{NaCl}$ can maintain the plants' growth (Benzarti et al. 2014). Munns (1992) concluded that the salts absorbed by plants do not control growth directly, but it influences turgor, photosynthesis, and/or the activity of specific enzymes. According to Kotagiri and Kolluru (2017), plant growth is affected by reduction in the water uptake, lack of nutrients, and accumulation of toxic sodium and chloride ions. 


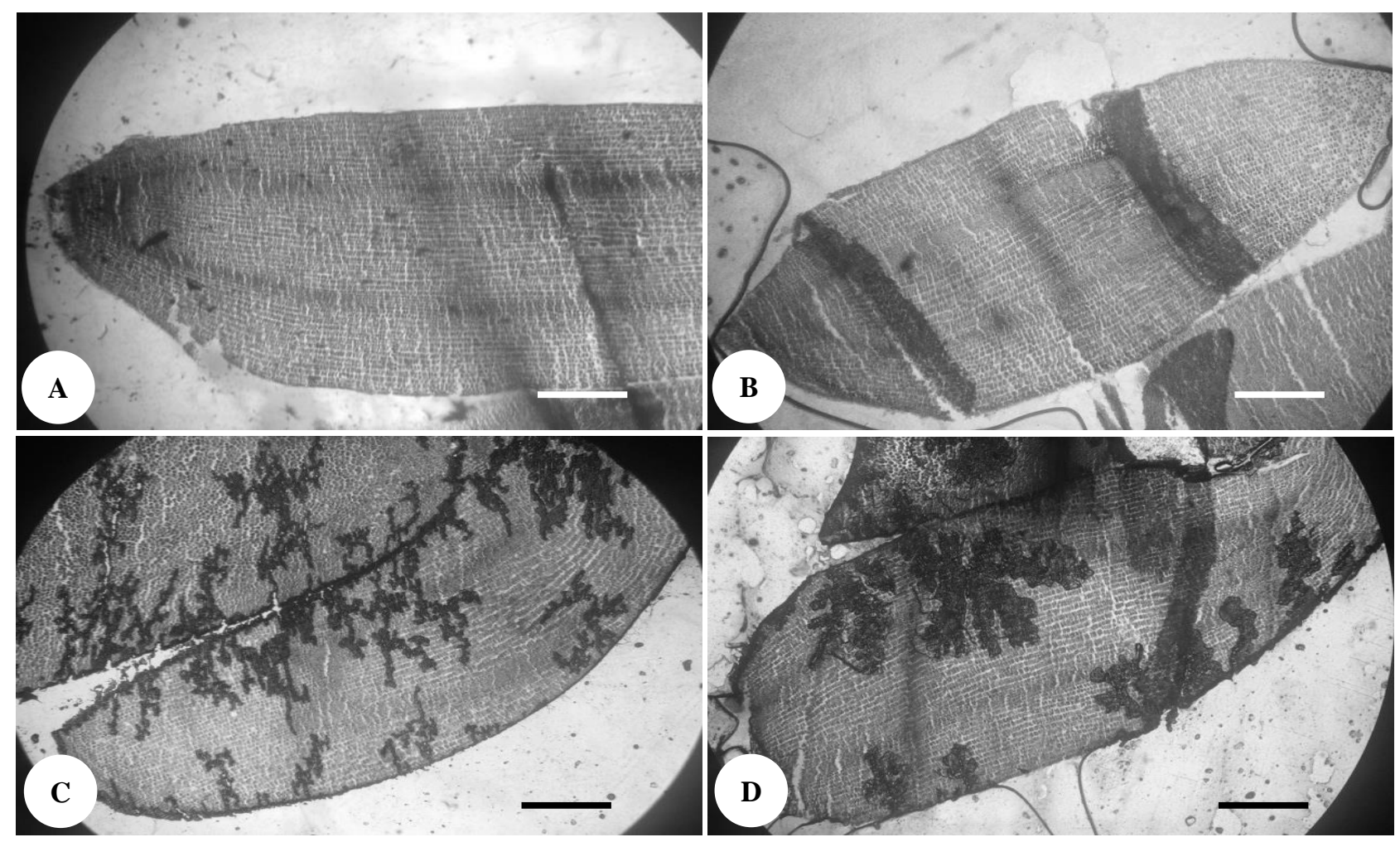

Figure 3. Anatomical characteristics of the seed radicle of Pterocarpus indicus forma indicus subjected to varying $\mathrm{NaCl}$ concentrations A. control (distilled water., B. $100 \mathrm{mM}$, C. $200 \mathrm{mM}$, and D. $300 \mathrm{mM}$ viewed under the Olympus compound microscope at 100x magnification; scale bar is $100 \mu \mathrm{m}$

Similar to other studies, high salt concentrations inhibit the production of new leaves on $P$. indicus $\mathrm{f}$. indicus seedlings and render leaves less turgid causing leaves to wilt easily. In some species like Physalis peruviana a reduction in the number of leaves could be already observed in as low as $60 \mathrm{mM} \mathrm{NaCl}$ (Miranda et al. 2014). Sohail et al. (2009) similarly observed a reduction (68\% and $72 \%$ ) in the number of leaves of Ziziphus spina-christi at 80 and $160 \mathrm{mM} \mathrm{NaCl}$, respectively. When plants cannot generate more leaves, photosynthesis is inhibited and consequently, its productivity. According to Dolatabadian (2012), one probable reason for the low leaf number is the inhibition of the formation of leaf primordia under salinity stress. Since leaf expansion is sensitive (Walker and Bernal 2008), the presence of $\mathrm{NaCl}$ is critical as it causes a decrease in leaf growth (Miranda et al. 2014).

Although no statistically significant difference was observed among treatments in terms of leaf area (Table 1), a decreasing tendency with increasing $\mathrm{NaCl}$ concentration could be observed. Cramer et al. (1994) and Curtis and Lauchli (1986) observed that the leaf area ratio is significantly reduced in some species under salt stress. However, in Z. spina-christi as mentioned previously, there was also a tendency of reduction in the leaf area with increasing salt concentration but not statistically different from the control. According to Munns (2002), with the plant's long-term exposure to $\mathrm{NaCl}$, they develop mechanisms to avoid excessive concentration of ions in the transpiring tissues as the leaves expand. High salt concentrations reduce plant growth (Munns and Tester 2008), and thus, limiting leaf expansion (Cramer 2002). The reduction of specific leaf area indicates that the leaf expansion and carbon allocation among the leaves are altered. Since it is the commonly used parameter to compare the thickness and/or density of leaves, this suggests that leaf area is primarily influenced by the environmental conditions such as availability of moisture, nutrients, and light, and changes in photosynthetic capacity like canopy size (Cunningham et al. 1999; Li et al. 2000; Pinkard and Beadle 1998). The seedlings also exhibited observable injuries in the leaves such as chlorosis and necrosis especially at 200 and $300 \mathrm{mM} \mathrm{NaCl}$. These were also seen in the study of Gupta et al. (2002) devoted to the Indian jujube subjected to 80 and $160 \mathrm{mM} \mathrm{NaCl}$ where severe foliar injuries and shedding of affected leaves were observed. According to Sohail et al. (2009), significant decline in the plant height and number of leaves lead to reduction in leaf area with increasing $\mathrm{NaCl}$ stress.

Similar to height, a decreasing trend is observed in the $\mathrm{RCD}$ of $P$. indicus $\mathrm{f}$. indicus with the increasing concentration of $\mathrm{NaCl}$ (Table 1). Jimenez-Casas and Zwiazek (2014) observed that Pinus leiophylla's stem diameter growth decreased with increasing $\mathrm{NaCl}$ concentration. Also, the RCD of a native dryland agroforestry tree species, Acacia tortilis, was severely impacted by salinity (Seid et al. 2016). For Senegalia senegal, Vachellia seyal, and Prosopis juliflora, Fall et al. (2016) observed that salinity reduced significantly the 
RCD. In contrast, salinity had no effect on the RCD of Balanites aegyptiaca (Seid et al. 2016). In addition, the greenhouse experiment of Duan (2015) demonstrated the effectiveness of $\mathrm{N}$ fertilization in improving the growth of seedlings in a saline growth media, resulting in improved RCD growth for both Pinus contorta and Picea glauca seedlings.

The effect of $\mathrm{NaCl}$ on nodulation has been examined in several investigations (e.g., Ikeda et al. 1992; Delgado et al. 1994; El-Hamdaoui et al. 2003; Kekere 2014). For example, acetylene reduction activity and respiration of the alfalfa nodules decreased to $96 \%$ and $84 \%$ at $210 \mathrm{mM}$ $\mathrm{NaC} 1$, and to $48 \%$ and $68 \%$ at $420 \mathrm{mM}$, respectively (Ikeda et al. 1992). Also, when salt was added directly to the incubation mixture of bacteroids, the $\mathrm{O}_{2}$ uptake of bacteroids isolated from nodules of pea and faba-bean was inhibited (Delgado et al. 1994). Moreover, salinity produced a decrease in $\mathrm{B}$ and $\mathrm{Ca}$ contents in nodulated roots of Pisum sativum. Lastly, it was observed by Kekere (2014) that root nodules of Arachis hypogaea declined with increase in $\mathrm{NaCl}$ concentration. Similarly to this study, the decreased production of root nodules with increase in $\mathrm{NaCl}$ concentration was observed in other Fabaceae species such as Acacia ehrenbergiana and A. tortilis (Al-Shaharani and Shetta 2011) and Sesbania rostrata (Joshua et al. 1995). However, in the study of Borucki and Sujkowska (2008) on Pisum sativum the use of $25 \mathrm{mM} \mathrm{NaCl}$ stimulated the root nodule formation compared to the control. According to Frankow-Lindberg and Dahlin (2013), the ease in plant activity reduces the nitrogen fixation of plants caused by any stress. The effect of salinity on nitrogen fixation processes can be discussed in terms of total nodule dry weight per plant and the nitrogen-fixing activity of nodule (Reddell and Bowen 1985).

While there is also a tendency of decrease in root-shoot ratio with increase in $\mathrm{NaCl}$ concentration in this study, significant reduction was detected only at the $300 \mathrm{mM}$ $\mathrm{NaCl}$ concentration (Table 1). Viégas et al. (2001) similarly observed low root-shoot ratio at increase in the $\mathrm{NaCl}$ concentration $\left(0,50\right.$, and $\left.100 \mathrm{~mol} \mathrm{~m}^{-3}\right)$ in Anacardium occidentale. Conversely, Àlvarez and Sánchez-Blanco (2014) observed an increased root-shoot ratio and improved the root system in Callistemon citrinus plants using saline water. Similarly, Acosta-Motos et al. (2015) observed increase in the root-shoot ratio in Myrtus communis plants irrigated for one month with $\mathrm{NaCl}$ solution with an EC of $8 \mathrm{dS} \mathrm{m}^{-1}$. The increase or decrease in shoot to root ratio is a common response to salt stress, which is related to factors associated with water stress (osmotic effect) rather than a salt-specific effect (Hsiao and $\mathrm{Xu}$ 2000). High salt concentrations result in changing the relationship between the aerial and root parts (Tattini et al. 1995).

Seed germination is the most crucial stage in a plant's life cycle. And when seeds are exposed to saline soils it can be critical to their salt tolerance levels (Khan et al. 2000 as cited by $\mathrm{Li}$ 2008). In this study, the increase in concentration of $\mathrm{NaCl}$ significantly reduced the germination of $P$. indicus f. indicus seeds (Figure 1A). Previous studies in Cedrela odorata (Ferreira et al. 2013),
Melaleuca quinquenervia (Martins et al. 2011), and $P$. tatarinowii (Fang et al. 2006) also showed the adverse effects of $\mathrm{NaCl}$ on the speed and percentage of seed germination. Specifically in $P$. tatarinowii, the seed germination was significantly inhibited by $\mathrm{NaCl}$ concentration exceeding $17 \mathrm{mM}$. Seed germination shows that most of the seeds attain their maximum germination under the control experiment and become very sensitive to increase in salinity (Li 2008). Salt stress negatively affects the germination of the seeds, osmotically through reduction of water or ionically by accumulation of $\mathrm{Na}^{+}$and $\mathrm{Cl}^{-}$ (Shokohifard et al. 1989), causing an imbalance in the nutrient uptake and making it toxic for the plant (Song et al. 2008).

The results showed that $P$. indicus f. indicus seedlings can tolerate certain amount of $\mathrm{NaCl}$ as there are still surviving seedlings at the $300 \mathrm{mM} \mathrm{NaCl}$ concentration (Figure 1B). However, the percent survival under this treatment was considerably low compared to other treatments. This response is the same as in the numerous plant species affected by salinity stress during germination (e.g., Katembe et al. 1998; Ghazy et al. 2009; Liu et al. 2010; Raddi et al. 2019). In the study of Fang et al. (2006), there was a significant reduction in the seedling survival with increase in $\mathrm{NaCl}$ concentration after 50 days of treatment. However, some species like the fast-growing leguminous trees, Acacia ampliceps and A. nilotica, can tolerate the high salinity level (Abbas et al. 2013). Seeds of halophytes or plants inhabiting highly saline waters have been found to germinate even after prolonged exposure to hypersaline conditions (Saranvanavel et al. 2018). According to Hasanuzzaman et al. (2014), some mangrove species, for example, Avicennia, Aegialitis, Aegiceras, and Acanthus possess multicellular salt glands and salt hairs to capture salt from mesophyll cells beneath them where a layer of salt crystals is formed. However, halophytic plants differ in the capacity to recover from exposure to salinity (Keiffer and Ungar 1997). Survival of the plants depends on all the factors available. But depending on the inherent nature of the species, plants may either adapt or die with the stress that causes them to deteriorate (Gull et al. 2019).

At varying levels of $\mathrm{NaCl}$, the $P$. indicus $\mathrm{f}$. indicus seedlings exhibited varying photosynthetic rates. Seedlings subjected to $\mathrm{NaCl}$ concentrations tend to increase to a certain photosynthetic active radiation (PAR), but later display fluctuating pattern as shown in Figure 2. Light responses of photosynthesis showed that net photosynthetic rate $\left(\mathrm{P}_{\mathrm{N}}\right)$ values were continuously raised with the increase of photosynthetic photon flux density (PPFD) at all salinity levels and plants treated with $600 \mathrm{mmol} \mathrm{L}^{-1}$ salinity suffered from photoinhibition with the lowest $\mathrm{P}_{\mathrm{N}}$ values (Qin et al. 2013). This negative response from the increased $\mathrm{NaCl}$ concentrations was also true in $P$. tatarinowii (Fang et al. 2006). Under salinity, when there is a reduction in photosynthetic rate, photo-oxidative damage to the photosynthetic machinery may happen (Mustafa et al. 2014). Romero-Aranda et al. (1998) studied anatomical disturbances produced by chloride salts (including $\mathrm{NaCl}$ ) in both sensitivity (Carrizo citrange) and tolerant (Cleopatra mandarin) citrus varieties. The salt-induced declines in net 
photosynthesis $\left(\mathrm{P}_{\mathrm{N}}\right)$ were linked to changes in the leaf anatomical properties such as the increase in leaf thickness and the lower area/volume ratio of mesophyll cells. Salinity also increased the succulence of leaves and reduced the intercellular air spaces, the surface/volume ratio of cells, and tissue density. More than $80 \%$ of the angiosperms are $\mathrm{C}_{3}$ plants wherein the photosynthetic $\mathrm{CO}_{2}$ assimilation $\left(\mu \mathrm{mol} \mathrm{m} \mathrm{m}^{-2} \mathrm{~s}^{-1}\right)$ follows the trend that at the maximum rate of photosynthesis as the saturation point, any further increase in photosynthetic active radiation (PAR) beyond this point will no longer result in more light fixation (Taiz and Zeiger 2003).

Figure 3 shows that at $100 \mathrm{mM} \mathrm{NaCl}$ the cells of the radicle tissue of $P$. indicus f. indicus started to show damages or disruptions of cells. This was also evident in the anatomical modifications of the radicle and hypocotyl of cotton induced by $\mathrm{NaCl}$ where the radicle growth decreased under 100 meq $\mathrm{L}^{-1}$ and $250 \mathrm{meq} \mathrm{L}^{-1}$ (Casenave et al. 1999). Given that there are distinguishable changes in the cell tissues of the radicle as the $\mathrm{NaCl}$ concentration increases, the assumption is that the ability of the radicle to become the primary root of the plant is inhibited (Koning 1994). Moreover, according to Bliss et al. (1984), salinity induces changes in the lipid composition of some plants, which serves as an important structural modification to achieve membrane compartmentation by separating the salts from sensitive cellular processes. As a result, the amount of $\mathrm{NaCl}$ or loss of water can cause some changes in the cell membrane.

In terms of morphological characteristics, the height and number of leaves showed significant changes in 200 $\mathrm{mM}$ and $300 \mathrm{mM} \mathrm{NaCl}$. Root collar diameter and number of nodules showed significant changes in $100 \mathrm{mM}, 200$ $\mathrm{mM}$, and $300 \mathrm{mM} \mathrm{NaCl}$. Root-shoot ratio only showed significant changes in $300 \mathrm{mM} \mathrm{NaCl}$, and leaf area did not show significant changes in all $\mathrm{NaCl}$ concentrations applied. In terms of physiological characteristics, germination and survival rates showed significant changes in $100 \mathrm{mM}$ to $300 \mathrm{mM} \mathrm{NaCl}$ while photosynthetic rate did not show significant changes to the $\mathrm{NaCl}$ concentrations. And in terms of anatomy, the radicle tissue showed immediate change in its cells under the $100 \mathrm{mM} \mathrm{NaCl}$ concentration. It can be concurred that using the $\mathrm{NaCl}$ concentrations from $100 \mathrm{mM}$ to $300 \mathrm{mM}$, the species can thrive in more than $100 \mathrm{mM}$ but less than $200 \mathrm{mM} \mathrm{NaCl}$ concentrations. In this study, the best parameters to measure the salt sensitivity of $P$. indicus are height, number of leaves, root collar diameter, root-shoot ratio, and anatomy of the seed as these showed significant changes after salt application and will determine if the species can really survive in saline conditions. The observed parameters are similar to the studies of Fang et al. (2006) for the height, Miranda et al. (2014) for the number of leaves, Jimenez-Casas and Zwiazek (2014) for root collar diameter, Viégas et al. (2001) for the roo-shoot ratio, and Casenave et al. (1999) for the radicle growth.

Therefore, it is concluded in this study that $P$. indicus $\mathrm{f}$. indicus seeds and seedlings can only tolerate up to moderate level of saline condition. The results of this study are crucial in using $P$. indicus as a reforestation species.
The species has limitations if planted in areas of high saline soil. Although $P$. indicus can only tolerate an appreciable amount of salts, its role as a nitrogen-fixing species will help facilitate the conversion of free nitrogen in the soil to ammonia, which the plant can utilize for its development.

\section{ACKNOWLEDGEMENTS}

The authors wish to thank the Department of Forest Biological Sciences and the Makiling Center for Mountain Ecosystems, College of Forestry and Natural Resources (DFBS, MCME - CFNR) - UPLB for allowing the use of facilities to conduct this study. This study is supported partly by the Department of Science and Technology through the Philippine Council for Agriculture, Aquatic and Natural Resources Research and Development (DOSTPCAARRD)-funded project "Germplasm Conservation of Selected Indigenous Forest Trees in Mount Makiling Forest Reserve (MMFR)".

\section{REFERENCES}

Abbas G, Saqib M, Akhtar J, Basra SMA. 2013. Salinity tolerance potential of two Acacia species at early seedling stage. Pak J Agric Sci 50 (4): 683-688.

Acosta-Motos, JR, Diaz-Vivancos P, Alvarez S, Fernández-Garcia N, Sánchez-Blanco MJ, Hernández JA. 2015. NaCl-induced physiological and biochemical adaptive mechanisms in the ornamental Mytrus communis L. plants. J Plant Physiol 183: 41-51.

Akcin TA, Akcin A, Yalcin E. 2017. Anatomical changes induced by salinity stress in Salicornia freitagii (Amaranthaceae). Braz J Bot 5: $1-6$.

Al-Shaharani TS, Shetta ND. 2011. Evaluation of growth, nodulation and nitrogen fixation of two acacia species under salt stress. World Appl Sci J 13 (2): 256-265.

Álvarez S, Sánchez-Blanco MJ. 2014. Long-term effect of salinity on plant quality, water relations, photosynthetic parameters and ion distribution in Callistemon citrinus. Plant Biol 16: 757-764.

Baek SG, Park JH, Na CS, Lee B, Cheng, HC, Woo SY. 2018. The morphological characteristics of Pterocarpus indicus induced by elevated ozone under well-watered and drought conditions. For Sci Technol 14: 106-111.

Baik SG, Woo SY. 2010. Physiological and biochemical responses of two tree species in urban areas to different air pollution levels. Photosynthetica 48: 23-29.

Bell AD. 2008. Plant Form: An Illustrated Guide to Flowering Plant Morphology. Oxford University Press, London.

Benzarti M, Rejeb KB, Messedi D, Mna AB, Hessini K, Ksontini M, Abdelly C, Debez A. 2014. Effect of high salinity on Atriplex portulacoides: Growth, leaf water relations and solute accumulation in relation to osmotic adjustment. S Afr J Bot 95: 70-77.

Bijanzadeh E, Emam Y. 2015. Effects of salt stress on root anatomy and hydraulic conductivity of barley cultivars. Iran Agric Res 34 (1): 7179.

Bliss RD, Aloia KAP, Thomson WW. 1984. Effects of salt on cell membranes of germination seeds. California Agric 38 (10): 24-25.

Borucki W, Sujkowska M. 2008. The effects of sodium chloride-salinity upon growth, nodulation, and root nodule structure of pea (Pisum sativum L.) plants. Acta Physiol Plant 30: 293-301.

Boughalleb F, Denden M, Tiba BB. 2009. Anatomical changes induced by increasing $\mathrm{NaCl}$ salinity in three fodder shrubs, Nitraria retusa, Atriplex halimus, and Medicago arborea. Acta Physiol Plant 31: 947960.

BSWM [Bureau of Soil and Water Management]. 2018. National Soil and Water Resources Research and Development/Extension Agenda 2017-2022. www.bswm.da.gov.ph. 
Cachorro P, Olmos E, Ortiz A, Cerdá A. 1995. Salinity-induced changes in the structure and ultrastructure of bean root cells. Biol Plant 37: 273-283.

Casenave EC, Degano CA, Toselli ME, Catan EA. 1999. Statistical studies on anatomical modifications in the radicle and hypocotyl of cotton induced by $\mathrm{NaCl}$. Biol Res 32 (4)

Cekstere G, Karlsons A, Grauda D. 2015. Salinity-induced responses and resistance in Trifolium repens L. Urban Forestry \& Urban Greening 14 (2): 225-236

Cramer GR, Alberico GJ, Schmidt C. 1994. Leaf expansion limits dry matter accumulation of salt-stressed maize. Aust J of Plant Physiol 21 (5): 663-674

Cramer GR. 2002. Sodium-calcium interactions under salinity stress. In Läuchli A, Lüttge U (eds) Salinity: Environment-Plants-Molecules. Kluwer: Dordrecht, The Netherlands.

Cunningham SA, Summerhayes B, Westoby M. 1999. Evolutionary divergences in leaf structure and chemistry, comparing rainfall and soil nutrient gradients. Ecol Monogr 69: 569-588.

Curtis PS, Lauchli A. 1986. The role of leaf area development and photosynthetic capacity in determining growth of Kenaf under moderate salt stress. Aust J Plant Physiol 13: 553-565.

Dawood MG, Taiae HAA, Nassar RMA, Abdelhamid MT, Schmidhalter U. 2014. The changes induced in the physiological, biochemical, and anatomical characteristics of Vicia faba by the exogenous application of proline under seawater stress. S Afr J Bot 93: 54-63.

Dayan MD. 2004. Fungal Diseases of Forest Tree Seeds and Control Measures: A Guidebook. College, Laguna, Philippines: Ecosystems Research and Development Bureau, Department of Environment and Natural Resources.

Dayan MP, Reaviles RS. 1995. Seed Technology Manual of Some Reforestation Species. National Forestation Development Office and Ecosystems Research and Development Bureau.

Delgado MJ, Ligero F, Lluch C. 1994. Effects of salt stress on growth and nitrogen fixation by pea, faba-bean, common bean and soybean plants. Soil Biol Biochem 26: 371-376.

Dey AK, Guha P, Sharma M, Meshram MR. Comparison of differen methods of in-situ leaf area measurement of betel leaf (Piper betle L.). Intl J Recent Technol Eng 7 (6): 1512-1616.

Dolatabadian A, Rahimi-Dehgolan R, Sarvestani TZ, Rezazadeh SA 2012. Morphological and physiological characters of Aloe vera subjected to saline water irrigation. J Herbs, Spices Med Plants 18: 222-230.

Dolatabadian A, Sanavy SAMM, Ghanati F. 2011. Effect of salinity on growth, xylem structure and anatomical characteristics of soybean. Not Sci Biol 3 (1): 41-45

Duan. 2015. Nitrogen Availability and Salinity as Limiting Factors for Lodgepole Pine (Pinus contorta) and White Spruce (Picea glauca) Growth on Reclaimed Sites in the Athabasca Oil Sands Region in Alberta, Canada. [Dissertation]. University of Alberta, Canada.

El-Hamdaoui A, Redondo-Nieto M, Torralba B, Rivilla R, Bonilla I, Balaños L. 2003. Influence of boron and calcium on the tolerance to salinity of nitrogen-fixing pea plants. Plant Soil 251: 93-103.

Fahn A. 1967. Plant Anatomy. Pergamon Press Ltd., Oxford. 541 p.

Fall D, Bakhoum N, Fall F, Diouf F, Ly MO, Diouf M, Gully D, Hocher V, Diouf D. 2016. Germination, growth and physiological responses of Senegalia senegal (L.) Britton, Vachellia seyal (Delile) P. Hurter and Prosopis juliflora (Swartz) DC to salinity stress in greenhouse conditions. Afr J Biotech 15 (37): 2017-2027.

Fang SZ, Song LY, Fu XX. 2006. Effects of $\mathrm{NaCl}$ stress on seed germination, leaf gas exchange and seedling growth of Pteroceltis tatarinowii. J For Res 17: 185-188.

Ferreira EGBS, Matos VP, Sena, LHM, Oliveira RG, Sales AGFA. 2013. Germination and vigor process of Cedrela odorata $\mathrm{L}$. seeds under salt stress. Ciênc Florest 23 (1): 99-105.

Frankow-Lindberg BE, Dahlin AS. 2013. $\mathrm{N}_{2}$ fixation, $\mathrm{N}$ transfer, and yield in grassland communities including a deep-rooted legume or non-legume species. Plant Soil 370: 567-581.

Gazal RM, Blanche CA, Carandang WM. 2004. Root growth potential and seedling morphological attributes of narra (Pterocarpus indicus Willd.) transplants. Forest Ecology and Management 195 (1-2): 259266.

Ghazy MMED, Habashy MM, Kossa FI, Mohammady EY. 2009. Effects of salinity on survival, growth and reproduction of the water flea, Daphnia magna. Nat Sci 7 (11): 28-42.

Glenn E, Brown J, Blumwald E. 1999. Salt tolerance and crop potential of halophytes. Crit Rev Plant Sci 18: 227-255.
Gull A, Lone AA, Wani NUI. 2019. Biotic and Abiotic Stresses in Plants. IntechOpen, UK.

Gupta NK, Meena SK, Gupta S, Khandelwal SK. 2002. Gas exchange, membrane permeability and ion uptake in two species of Indian jujube differing in salt tolerance. Photosynthetica 40: 535-539.

Hasanuzzaman M, Zhou M, Shabala S. 2018. Physiological and morphological mechanisms mediating plant tolerance to osmotic stress. In: Benkablia N (ed) Climate Change and Crop Production: Foundations for Agroecosystems Resilience. CRC Press, Boca Raton, FL.

Hassan MA, Morosan M, López-Gresa MDP, Prohens J, Vicente O, Boscaiu M. 2016. Salinity-induced variation in biochemical markers provides insight into the mechanisms of salt tolerance in common (Phaseolus vulgaris) and runner (P. coccineus) beans. Int J Mol Sci 17 (9): 1582.

Haupt AW. 1953. Plant Morphology. McGraw-Hill \& University of Michigan, USA

Hsiao TC, Xu LK. 2000. Sensitivity of growth of roots versus leaves to water stress: Biophysical analysis and relation to water transport. J Exp Bot 51: 1595-1616

Huang J, Redmann RE. 1995. Responses of growth, morphology, and anatomy to salinity and calcium supply in cultivated and wild barley. Can J Bot 73 (12): 1859-1866.

Ikeda JL, Kobaysahi M, Takahashi E. 1992. Salt stress increases the respiratory cost of nitrogen fixation. J Soil Sci Plant Nutr 38: 51-56.

Jafri AZ, Ahmad R. 1995. Effect of soil salinity on leaf development, stomatal size and its distribution in cotton (Gossypium hirsutum L.). Pak J Bot 27 (2): 297-303.

Jimenez-Casas M, Zwiazek JJ. 2014. Adventitious sprouting of Pinus leiophylla in response to salt stress. Ann For Sci 71 (7): 811-819.

Joshua DC, Ramani S, Shaikh MS. 1995. Growth, nodulation, stem anatomy and nitrogen content of Sesbania rostrata grown in different salinity levels. Curr Sci 68 (9): 963-965.

Katembe W, Ungar IA, Mitchell JP. 1998. Effect of salinity on germination and seedling growth of two Atriplex species (Chenopodiaceae). Ann Bot 82: 167-175.

Keiffer CH, Ungar IA. 1997. The effect of extended exposure to hypersaline conditions on the germination of five inland halophyte species. Am J Bot 84: 105-111.

Kekere O. 2014. Growth, yield and seed nutritional composition of groundnut (Arachis hypogaea L.) under elevated level of soil salinity. Mol Soil Biol 5 (5): 31-38.

Koning RE. 1994. Seeds and Seed Germination. Plant Physiology Information. http://plantphys.info/plants_human/seedgerm.shtml.

Kotagiri D, Kolluru VC. 2017. Effect of salinity stress on the morphology and physiology of five different Coleus species. Biomed Pharmacol J 10 (4): 1639-1649.

Kozlowski TT, Pallardy SG. 1997. Physiology of woody plants. Academic Press, San Diego.

Krishnapillay B, Marzalina M, Alang ZC. Cryopreservation of whole seeds and excised embryos of Pterocarpus indicus. J Trop Forest Sci 7 (2): 313-322.

Ku-Or Y, Leksungnoen N, Onwinom D, Doomil P. 2020. Germination and salinity tolerance of seeds of sixteen Fabaceae species in Thailand for reclamation of salt-affected lands. Biodiversitas 21: 2188-2200.

Li CY, Berninger F, Koskela J, Sonninen E. 2000. Drought responses of Eucalyptus microtheca provenances depend on seasonality of rainfall in their place of origin. Aust J Plant Physiol 27: 231-238.

Li Y. 2008. Effect of salt stress on seed germination and seedling growth of three salinity plants. Pak J Biol Sci 11 (9): 1268-1272.

Liu J, Gui WQ, Shi DC. 2010. Seed germination, seedling survival, and physiological response of sunflowers under saline and alkaline conditions. Photosynthetica 48: 278-286.

Lok EH, Dell B. 2015. Phosphorus requirements for containerized Pterocarpus indicus seedlings. J For Res 26: 657-662.

Martins CC, Pereira, MRR, Marchi SR. 2011. Germination of Melaleuca quinquenervia seeds under water and salt stress conditions. Planta Daninha 29 (1): 1-6.

Miranda D, Fischer G, Mewis I, Rohn S, Ulchris C. 2014. Salinity effects on proline accumulation and total antioxidant activity in leaves of the cape gooseberry (Physalis peruviana L.). J Appl Bot Food Qual 87: 67-73.

Mishra RK, Dash A, Pattanaik S, Nayak PK, Mohanty RC. 2015. Seed germination and seedling survival percentage of Shorea robusta Gaertn.f. in buffer areas of Similipal Biosphere Reserve, Odisha, India. J Ecosys Ecograph 4:153. 
Munns R, Tester M. 2008. Mechanisms of salinity tolerance. Ann Rev Plant Biol 59: 651-681.

Munns R. 1992. A leaf elongation assay detects an unknown growth inhibitor in xylem sap from wheat and barley. Aust J Plant Physiol 19: $127-135$.

Munns R. 2002. Physiological processes limiting plant growth in saline soils: some dogmas and hypotheses. Plant Cell Environ 16: 5-24.

Mustafa Z, Pervez MA, Ayyub CM, Matloob A, Khaliq A, Hussain S, Ihsan MZ, Butt M. 2014. Morpho-physiological characterization of chili genotypes under $\mathrm{NaCl}$ salinity. Soil Environ 33 (2): 133-141.

Naidoo G, Mundree SG. 1993. Relationship between morphological and physiological responses to waterlogging and salinity in Sporobolus virginicus (L.) Kunth. Oecol 93: 360-366.

Patel NT, Vaghela PM, Patel AD, Pandey AN. 2011. Implications of calcium nutrition on the response of Caesalpinia crista (Fabaceae) to soil salinity. Acta Ecologica Sinica 31 (1): 24-30.

Pinkard EA, Beadle CL. 1998. Aboveground biomass partitioning and crown architecture of Eucalyptus nitens following green pruning. Can J For Res 28: 1419-1428.

Poljakoff-Mayber A. 1975. Morphological and anatomical changes in plants as a response to salinity stress. In: Poljakoff-Mayber A, Gale J (eds.). Plants in Saline Environments. Ecological Studies (Analysis and Synthesis), Vol. 15. Springer, Berlin.

Qadir M, Quillerou E, Nangia V, Murtaza G, Singh M, Thomas RJ, Drechsel P, Noble AD. 2014. Economics of salt-induced land degradation and restoration. Nat Res Forum 38 (4): 282-295.

Qin J, Dong WY, He, KN, Yu Y, Tan GD, Han L, Dong M, Zhang YY, Zhang D, Li AZ, Wang ZL. 2013. NaCl salinity-induced changes in water status, ion contents and photosynthetic properties of Shepherdia argentea (Pursh) Nutt. seedlings. World J Agric Sci 9 (4): 305-308.

Raddi S, Mariotti B, Martini S, Pierguidi A. 2019. Salinity tolerance in Fraxinus angustifolia Vahl.: Seed emergence in field and germination trials. Forests 10 (940): 1-18.

Rajabpoor S, Kiani S, Sorkheh K, Tavakoli F. 2014. Changes induced by osmotic stress in the morphology, biochemistry, physiology, anatomy and stomatal parameters of almond species (Prunus L. spp.) grown in vitro. J For Res 25: 523-534.

Reddell P, Bowen GD. 1985. Frankia source affects growth nodulation and nitrogen fixation in Casuarina species. New Phytol 100: 111-122.

Rogers ER, Zalesny, Jr. RS, Hallett RA, Headlee WL, Wise AH. 2019. Relationships among root-shoot ratio, early growth, and health of hybrid poplar and willow clones grown in different landfill soils. Forests 10 (49): 1-18.

Romero-Aranda R, Moya JL, Tadeo FR, Legaz F, Primo-Millo E, Talon M. 1998. Physiological and anatomical disturbances induced by chloride salts in sensitive and tolerant citrus: Beneficial and detrimental effects of cations. Plant Cell Environ 21: 1243-1253.
Sanchez RA. 1967. Some observations about the effect of light on the leaf shape in Taraxacum officinale L. Meded. Landbouwhogeschool Wageningen 67 (16): 1-22.

Saravanavel R, Ranganathan R, Anantharaman P, Mathevanpillai M, Silambarasan G. 2012. Effect of sodium chloride on seed germination and seedling growth of Avicennia officinalis L. seedlings. Planta Activa 4: 1-4.

Seid H, Birhane E, Kebede F, Hadgu KM, negussie A, Norgrove L. 2016. Response of selected indigenous dryland agroforestry tree species to salinity and implications for soil fertility management. Agrofor Sys 90: 1133-1142.

Shipunov A. 2020. Introduction to Botany. Minot State University, North Dakota, USA

Shokohifard G, Sakagami K, Hamada R, Matsumoto S. 1989. Effect of amending materials on growth of radish plant in salinized soil. J Plant Nutr 12 (10): 1195-1214.

Sianipar NF, Purnamaningsih R, Darawti I, Laurent D, Chelen. 2015. The effects of gamma irradiation and somaclonal variation on morphology variation of mutant rodent tuber (Typhonium flagelliforme Lodd.) lines. KnE Life Sci 2: 637-645.

Sohail M, Saied A, Gebauer J, Buerkert A. 2009. Effect of $\mathrm{NaCl}$ salinity on growth and mineral composition of Ziziphus spina-christi (L.) Willd. J Agric Rural Dev Trop 110 (2): 107-114.

Song J, Fan H, Zhao Y, Jia Y, Du X, Wang B. 2008. Effect of salinity on germination, seedling emergence, seedling growth and ion accumulation of a euhalophyte Suaeda salsa in an intertidal zone and on saline inland. Aquat Bot 88 (4): 331-337.

Taiz L, Zeiger E. 2003. Plant physiology, 3rd ed. Sinauer Associates, Sunderland, MA.

Tattini M, Gucci R, Coradeschi MA, Ponzio C, Everard JD. 1995. Growth, gas exchange and ion content in Olea europaea plants during salinity stress and subsequent relief. Physiol Plant 95: 203-210.

Thomson LAJ. 2006. Pterocarpus indicus (narra), ver. 2.1. In: Elevitch, CR (ed.). Species Profiles for Pacific Island Agroforestry. Permanent Agriculture Resources (PAR), Hōlualoa, Hawai'i. http://www.traditionaltree.org

Viégas, RA, da Silveira JAG, de Lima Jr AR, Queiroz JE, Fausto MJM. 2001. Effects of $\mathrm{NaCl}$-salinity on growth and inorganic solute accumulation in young cashew plants. Rev Bras Eng Aric Ambient 5 (2): 216-222

Vijayan K, Chakraborti SP, Ercisli S, Ghosh PD. 2008. $\mathrm{NaCl}$ induced morpho-biochemical and anatomical changes in mulberry. Plant Growth Regul 56: 61-69.

Walker DJ, Bernal MP. 2008. The effects of olive mill waste compost and poultry manure on the availability and plant uptake of nutrients in highly saline soil. Bioresour Technol 99 (2): 396-403.

Xu CX, Zeng J, Cui TC, Chen QD, Ma. YP. 2016. Introduction, growth performance and ecological adaptability of hongmu tree species (Pterocarpus spp.) in China. J Trop For Sci 23 (3): 260-267. 